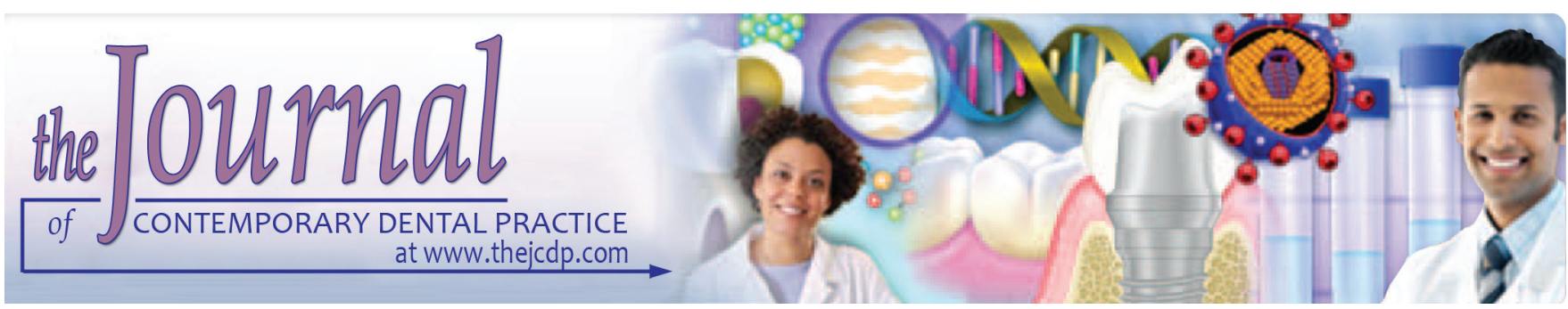

\title{
Antimicrobial Potential of Laser Diode in Infected Dentin
}

\author{
${ }^{1}$ Cyntia Rde A Estrela, ${ }^{2}$ Jefferson D de Oliveira, ${ }^{3}$ Fabio C Tirintan, ${ }^{4}$ Rodrigo Guapo-Pavarina, ${ }^{5}$ Thiago M Pereira \\ ${ }^{6}$ Matheus C Bandeca, ${ }^{7}$ Mateus R Tonetto, ${ }^{8}$ Suellen L Lima, ${ }^{9}$ Fábio LM Pedro, ${ }^{10}$ Álvaro H Borges
}

\section{ABSTRACT}

Aim: To evaluate the antibacterial effect of diode laser, associated or not with $2.5 \%$ sodium hypochlorite $(\mathrm{NaOCl})$, against Enterococcus faecalis.

Materials and methods: Eighty dentin blocks were obtained from single-rooted human teeth and sterilized. Seventy were inoculated with $0.01 \mathrm{~mL}$ of fresh bacterial inoculum (within 24 hours of preparation from pure culture) standardized to 1 McFarland turbidity. Contaminated blocks were incubated for 7 days at $37^{\circ} \mathrm{C}$ in humid conditions. Ten uncontaminated samples were incubated at $37^{\circ} \mathrm{C}$ during the contamination period to serve as a negative control group, while 10 of the infected specimens served as a positive control group. The dentin blocks were randomly divided into eight experimental groups ( $\mathrm{n}=10$ each) according to the method of decontamination: $2.5 \% \mathrm{NaOCl}$ alone; $2.5 \% \mathrm{NaOCl}+$ photodynamic therapy (PDT) with methylene blue/660 nm laser at $18 \mathrm{~J}$ for 180 seconds; $2.5 \% \mathrm{NaOCl}+$ PDT with methylene blue $/ 660 \mathrm{~nm}$ laser at $8 \mathrm{~J}$ for 80 seconds; methylene blue alone; PDT alone with methylene blue/660 $\mathrm{nm}$ laser at $18 \mathrm{~J}$ for 180 seconds; PDT alone with methylene blue/660 $\mathrm{nm}$ laser at $8 \mathrm{~J}$ laser for 80 seconds; positive control group; and negative control group. Microbial growth was evaluated by culture medium turbidity and microbial concentration was analyzed by UV spectrophotometry (adjusted to read at wavelength $I=600 \mathrm{nM}$ ).

Results: Root canals treated with laser alone at $18 \mathrm{~J}$ for 180 seconds had higher bacterial contamination compared with groups in which $\mathrm{NaOCl}$ was used, with or without laser irradiation at $18 \mathrm{~J}$ for 180 seconds $(p<0.05)$.

Conclusion: Photodynamic therapy with a $660 \mathrm{~nm}$ diode laser effectively reduced $E$. faecalis contamination. These findings

1-5,7,9,10Department of Post-Graduate Program in Integrated Dental Science, University of Cuiabá, Cuiabá, Mato Grosso Brazil

${ }^{6,8}$ Department of Post-Graduate Program in Dentistry, CEUMA University, São Luis, Maranhão, Brazil

Corresponding Author: Álvaro H Borges, Avenida Manoel José de Arruda, 3100, Jardim Europa, 78065900, Cuiabá, Mato Grosso, Brazil, e-mail: alvarohborges@gmail.com can guide development of further studies in search of better alternatives for endodontic treatment.

Clinical relevance: Chemical and mechanical root canal preparation plays an essential role in reducing microbial burden. However, microorganisms present in areas not mechanically reachable by endodontic instruments. As an alternative to fix this problem, the laser can be applied.

Keywords: Dentin, Enterococcus faecalis, Phototherapy.

How to cite this article: Estrela CRA, de Oliveira JD, Tirintan FC, Guapo-Pavarina R, Pereira TM, Bandeca MC, Tonetto MR, Lima SL, Pedro FLM, Borges ÁH. Antimicrobial Potential of Laser Diode in Infected Dentin. J Contemp Dent Pract 2018;19(8):904-909.

Source of support: Nil

Conflict of interest: None

\section{INTRODUCTION}

Chemical and mechanical root canal preparation play an essential role in reducing microbial burden. However, microorganisms present in areas not mechanically reachable by endodontic instruments, such as the dentinal tubules, isthmus, lateral canals, and apical ramifications, can lead to treatment failure. ${ }^{1}$ Enterococcus faecalis is a facultative anaerobic Gram-positive bacterium rarely found in cases of primary endodontic infections, but which may represent 38 to $70 \%$ of the microbiota in cases of retreatment. ${ }^{2}$ Enterococcus faecalis has a unique biofilm formation strategy, virulence factors, adhesion to dentin collagen, survival in critical medium, and resistance to endodontic therapy. ${ }^{3}$

In endodontics, microbial elimination is a particular challenge due to the complexity of the root canal system. ${ }^{4,5}$ Periapical lesions that persist after appropriate endodontic treatment are caused by the permanence of pathogenic bacteria within the root canals. ${ }^{6}$ Irrigation is a critical part of the canal cleaning process, and irrigant solutions are expected to act in areas where endodontic instruments cannot reach. ${ }^{4,7}$ A variety of solutions have 
been proposed, but none possesses all desired characteristics of an optimal irrigant; thus, various combinations of products and protocols have been tested. ${ }^{8}$

Photodynamic therapy stands out as a potential therapeutic approach to improve root canal cleaning. ${ }^{9}$ This therapy is based on the organic reaction of photooxidation. ${ }^{9}$ Application of a photosensitizing agent is followed by a dose of low-level laser radiation at a suitable wavelength. ${ }^{10}$ The absorption of light activates the photosensitizer, which, in the presence of oxygen, triggers a cascade of photochemical effects that result in the production of highly reactive oxygen species, which are toxic to tumor cells, bacteria, and fungi. ${ }^{10}$

Within this context, the purpose of present study was to evaluate the antibacterial effect of diode laser irradiation, combined or not with $2.5 \%$ sodium hypochlorite $(\mathrm{NaOCl})$ irrigation, against $E$. faecalis in contaminated human dentin blocks.

\section{MATERIALS AND METHODS}

This study was approved by Research Ethics Committee of Universidade Federal de Goiás, Brazil (CAAE 19811113.0.0000.5083).

\section{Dentin Blocks Preparation}

Selected teeth had fully formed roots and exhibited no defects, no internal or external root resorption, and no calcified canals. These criteria were checked through radiographic examination, mesiodistal and buccolingual viewing through a magnifying glass, and exploration of the root canal with a \#15 K-file. Sequentially, eighty dentin blocks were obtained from single-rooted human teeth extracted for periodontal or prosthetic reasons.

The extracted teeth were placed in a $0.2 \%$ thymol solution until the dentin blocks could be obtained. Roots were sectioned on an Extec Labcut 1010 Low Speed cutting machine with a diamond saw (Buehler, Illinois, USA) under abundant air/water cooling. Dentin disks obtained from the cervical third of the root were cut into four specimens to yield dentin blocks $4 \mathrm{~mm}$ in height $\times 4 \mathrm{~mm}$ in length. The dimensions were verified using a digital caliper (Mitutoyo, São Paulo, Brazil) and, if necessary, corrected with a fine polishing disk (3M ESPE Dental Products, Minnesota, USA). Once each block was properly dimensioned, its outer surface was insulated with two layers of nail polish (Max Factor Cosmetics and Fragrances, London, UK) to prevent infiltration. The specimens were washed twice by sonication (Cristofoli, Paraná, Brazil) for 5 minutes in 17\% ethylenediaminetetraacetic acid (Fórmula and Ação, São Paulo, Brazil) and left to soak for 10 minutes in sterile distilled water. The dentin blocks were sterilized in an autoclave (Cristofoli, Paraná,
Brazil) for 30 minutes at $120^{\circ} \mathrm{C}$ and incubated in $7 \mathrm{~mL}$ of Brain Heart Infusion (BHI) medium (Difco Laboratories, Michigan, USA) at $37^{\circ} \mathrm{C}$ for 48 hours to ensure sterilization. After this period, no bacterial growth was observed.

\section{Biological Indicator}

For the present study, samples of the microorganism E. faecalis (ATCC 29212) were selected. The strain was inoculated into $7 \mathrm{~mL} \mathrm{BHI}$ and incubated at $37^{\circ} \mathrm{C}$ for 24 hours. The microorganism was also grown in $\mathrm{BHI}$ surface under the same incubation conditions. Microbial cells were suspended in saline to McFarland turbidity standard 1, giving a final concentration of approximately $3 \times 10^{8}$ cells $/ \mathrm{mL}$.

\section{Contamination of Dentin Blocks}

The dentin blocks were inoculated with $0.01 \mathrm{~mL}$ of the aforementioned bacterial inoculum at 24 hours of preparation. Contaminated blocks were incubated for 7 days, at $37^{\circ} \mathrm{C}$, in humid conditions.

Ten uncontaminated samples were incubated at $37^{\circ} \mathrm{C}$ during the contamination period to test the sterility of the samples that would serve as the negative control group. Ten infected specimens were likewise incubated at $37^{\circ} \mathrm{C}$ throughout the trial period to serve as a positive control group and assess the viability of the biological indicator.

\section{Experimental Irrigant}

The irrigant solution tested in this experiment was 2.5\% $\mathrm{NaOCl}$ (Plant Protection, GO, Brazil).

\section{Photodynamic Therapy}

For the purposes of this study, PDT was administered by application of a low-level diode laser in the red spectrum (wavelength $660 \mathrm{~nm}$; SiroLaser, Dentsply Sirona, Bensheim, Germany). Irradiation was performed in continuous mode at two power levels and durations: $18 \mathrm{~J}$ (for 180 seconds) and $8 \mathrm{~J}$ (for 80 seconds).

\section{Study Design}

Contaminated dentin blocks were randomly divided into six groups, each of which received one of the following decontamination methods:

Group I ( $\mathrm{NaOCl}$ alone): Dentin blocks were submerged in $5 \mathrm{~mL}$ of $2.5 \% \mathrm{NaOCl}$ solution for 5 minutes. Subsequently, each block was rinsed with $5 \mathrm{~mL}$ of sterile distilled water, transferred individually into $7 \mathrm{~mL}$ BHI to which sodium thiosulfate (PA Art Laboratories, São Paulo, Brazil) and Tween 80 were added in appropriate concentrations, and incubated at $37^{\circ} \mathrm{C}$ for 48 hours.

Groups II and III (NaOCl plus PDT): Dentin blocks were submerged in $5 \mathrm{~mL}$ of $2.5 \% \mathrm{NaOCl}$ solution for 
5 minutes. Subsequently, each block was rinsed with $5 \mathrm{~mL}$ of sterile distilled water, transferred individually into Dappen dishes containing $0.001 \%$ methylene blue as photosensitizer (Phloraceae Farmácia de Manipulação, Cuiabá, Mato Grosso, Brazil), where they remained for 3 minutes (preirradiation period). Then, specimens were again rinsed with $5 \mathrm{~mL}$ of sterile distilled water, and laser irradiation was performed. After irradiation, each block was transferred individually into $7 \mathrm{~mL} \mathrm{BHI}$ to which sodium thiosulfate (PA Art Laboratories, São Paulo, Brazil) and Tween 80 were added at appropriate concentrations, and incubated at $37^{\circ} \mathrm{C}$ for 48 hours. Group II specimens received diode laser irradiation at $18 \mathrm{~J}$ for 180 seconds, while group III specimens were irradiated at $8 \mathrm{~J}$ for 80 seconds.

Group IV (Methylene blue alone): Dentin blocks were submerged in $0.001 \%$ methylene blue, where they remained for 3 minutes, followed by rinsing with $5 \mathrm{~mL}$ of sterile distilled water. The specimens were then transferred individually into $7 \mathrm{~mL} \mathrm{BHI}$ to which sodium thiosulfate and Tween 80 were added at appropriate concentrations, followed by incubation at $37^{\circ} \mathrm{C}$ for 48 hours.

Groups V and VI (PDT alone): Dentin blocks were submerged in $0.001 \%$ methylene blue, where they remained for 3 minutes, followed by rinsing with $5 \mathrm{~mL}$ of sterile distilled water and laser irradiation. After irradiation, each block was transferred individually into $7 \mathrm{~mL} \mathrm{BHI}$ to which sodium thiosulfate and Tween 80 were added at appropriate concentrations, and incubated at $37^{\circ} \mathrm{C}$ for 48 hours. Group V specimens received diode laser irradiation at $18 \mathrm{~J}$ for 180 seconds, while group VI specimens were irradiated at $8 \mathrm{~J}$ for 80 seconds.

\section{Microbiological Analysis}

Microbial growth was assessed by turbidity of the culture medium. Thereafter, a $0.1 \mathrm{~mL}$ inoculum of the BHI obtained was transferred to $5 \mathrm{~mL}$ of Letheen Broth under identical incubation conditions. Gram staining was performed on all BHI cultures to check for contamination and growth, and all were examined macroscopically and microscopically. The microbial concentration was analyzed in a UV spectrophotometer (New Model 1600 UV, São Paulo, Brazil) set to read at a wavelength of $600 \mathrm{~nm}$.

\section{Statistical Analysis}

All results were expressed as means and analyzed via the nonparametric Kruskal-Wallis and Mann-Whitney tests (Wilcoxon rank-sum tests) at the 5\% significance level.

\section{RESULTS}

Table 1 lists means and standard deviations (SDs) for the spectrophotometry data assessed in the different
Table 1: Means and SDs of spectrophotometry values for specimens in each disinfection protocol group, before (initial) and after (final) disinfection

\begin{tabular}{lll}
\hline Disinfection protocol & Initial & Final \\
\hline $2.5 \% \mathrm{NaOCl}$ & $0.818 \pm 0.086^{\mathrm{a}}$ & $0.181 \pm 0.098^{\mathrm{b}}$ \\
$2.5 \% \mathrm{NaOCl}+$ PDT with & $0.781 \pm 0.054^{\mathrm{a}}$ & $0.208 \pm 0.011^{\mathrm{b}}$ \\
methylene blue/18 J laser & & \\
$\begin{array}{l}180 \mathrm{sec}) \\
2.5 \% \mathrm{NaOCl}+\text { PDT with } \\
\text { methylene blue/8 J laser }\end{array}$ & $0.863 \pm 0.043^{\mathrm{a}}$ & $0.207 \pm 0.127^{\mathrm{b}}$ \\
$\begin{array}{l}\text { (80 sec) } \\
\text { Methylene blue }\end{array}$ & $0.772 \pm 0.031^{\mathrm{a}}$ & $0.364 \pm 0.038^{\mathrm{b}}$ \\
$\begin{array}{l}\text { PDT with methylene blue/18 } \\
\text { J laser (180 sec) }\end{array}$ & $0.874 \pm 0.041^{\mathrm{a}}$ & $0.342 \pm 0.020^{\mathrm{b}}$ \\
$\begin{array}{l}\text { PDT with methylene blue/8 } \\
\text { J laser (80 sec) }\end{array}$ & $0.779 \pm 0.048^{\mathrm{a}}$ & $0.356 \pm 0.018^{\mathrm{b}}$ \\
\hline
\end{tabular}

Different letters indicate statistically significant differences between columns

experimental conditions, for both initial (before root canal cleaning) and final analysis (after root canal cleaning). Analysis of the distribution of random errors around the mean by the Shapiro-Wilk test showed a non-normal distribution $(\mathrm{p}<0.05)$ at the initial and final time points. Thus, for comparison of data between different root canal cleaning methods at each time point (unpaired samples), the Kruskal-Wallis test was used; statistically significant differences $(p<0.001)$ were found before and after sanitization. Given these results, the comparison of spectrophotometry data after root canal cleaning could be biased, as differences were already present at the initial time point. Thus, the least squares method was used for correction of final spectrophotometry data. To compare data between the initial and final periods (paired data), Wilcoxon's rank-sum test was used, and revealed a statistically significant difference $(\mathrm{p}<0.001)$. After root canal cleaning, there was a significant reduction in microbial burden, as revealed by lower values found on spectrophotometry.

Initially, a linear regression analysis between the initial and final data was carried out to check for correlation between them. This analysis showed no statistical significance $(\mathrm{p}<0.001)$. The angular coefficient was recorded (0.434) and a standard initial spectrophotometry value was obtained by averaging the values of the different groups (0.817). These data were then entered into the following equation: [Spectrophotometry ${ }_{\text {adjusted }}=$ final specimen spectrophotometry value + angular coefficient* (initial specimen spectrophotometry - standard spectrophotometry value)].

Table 2 shows the means and SDs of the data obtained with this calculation. This new dataset, now adjusted to the standard initial spectrophotometry value (except for the negative control group), was analyzed as to the distribution of random errors around the mean by the Shapiro-Wilk test, which rejected the assumption of 
Table 2: Means and SDs of adjusted spectrophotometry values for specimens in each disinfection protocol group

\begin{tabular}{ll}
\hline Disinfection protocol & $\begin{array}{l}\text { Adjusted spectrophotometry } \\
\text { value }\end{array}$ \\
\hline $2.5 \% \mathrm{NaOCl}$ & $0.181 \pm 0.098^{\mathrm{a}, \mathrm{c}}$ \\
$2.5 \% \mathrm{NaOCl}+$ PDT with methylene & $0.192 \pm 0.127^{\mathrm{a}, \mathrm{c}, \mathrm{d}}$ \\
blue/18 J laser (180 sec) & $0.226 \pm 0.122^{\mathrm{a}, \mathrm{b}, \mathrm{c}, \mathrm{d}}$ \\
$2.5 \% \mathrm{NaOCl}+\mathrm{PDT}$ with & \\
methylene blue/8 J laser (80 sec) & $0.344 \pm 0.041^{\mathrm{a}, \mathrm{e}}$ \\
$\begin{array}{l}\text { Methylene blue } \\
\text { PDT with methylene blue/18 J }\end{array}$ & $0.367 \pm 0.032^{\mathrm{b}, \mathrm{e}}$ \\
laser (180 sec) & \\
$\begin{array}{l}\text { PDT with methylene blue/8 J laser } \\
\text { (80 sec) }\end{array}$ & $0.339 \pm 0.029^{\mathrm{a}, \mathrm{e}}$ \\
Positive control & $0.860 \pm 0.083^{\mathrm{e}}$ \\
Negative control & $0.000 \pm 0.000^{\mathrm{c}}$ \\
\hline
\end{tabular}

Different letters indicate statistically significant differences between the disinfection protocols

normality $(\mathrm{p}<0.05)$. Therefore, data were again analyzed using the Kruskal-Wallis test, which revealed statistically significant differences for different root canal cleaning methods $(\mathrm{p}<0.001)$. The nonparametric Tukey test revealed that bacterial contamination was higher in the positive control group than in all others $(\mathrm{p}<0.05)$, except those in which laser alone was used, regardless of the parameters employed, and the group in which methylene blue alone was used $(p>0.05)$. Root canals irradiated with the laser settings $18 \mathrm{~J} / 180$ seconds had higher bacterial contamination than the negative control group and the groups in which $\mathrm{NaOCl}$ was employed, with or without laser at $18 \mathrm{~J} / 180$ seconds $(\mathrm{p}<0.05)$. Differences were also found between the laser $8 \mathrm{~J} / 80$ seconds and negative control group, as well as between methylene blue alone and negative control $(\mathrm{p}<0.05)$. The other methods did not differ $(\mathrm{p}<0.05)$.

\section{DISCUSSION}

The results of this study showed a reduction in microbial burden after root canal cleaning, with significant differences $(p<0.001)$ among the different tested methods. As expected, the Tukey test showed that the positive control group had the highest bacterial contamination $(p<0.05)$. Root canals cleaned with a $660-\mathrm{nm}$ diode laser at $18 \mathrm{~J}$ for 180 seconds had higher bacterial contamination than the negative control group and the groups in which $\mathrm{NaOCl}$ irrigation was employed, with or without laser irradiation ( $p<0.05)$. Differences were also found between laser irradiation at $8 \mathrm{~J}$ for 80 seconds and negative control, as well as between cleaning with methylene blue alone and negative control $(\mathrm{p}<0.05)$. Enterococcus faecalis was chosen as the biomarker of contamination based on its presence in the root canal system, especially in teeth with endodontic treatment failure. ${ }^{11-16}$ The methodology applied in this study has been previously employed elsewhere, and the use of E. faecalis as a 7-day-old biofilm has already been described. ${ }^{17,18}$

The optimal irrigant solution and its ideal concentration have yet to be defined. Although some studies have shown that the optimal concentration of $\mathrm{NaOCl}$ for use in endodontic treatment ranges from 1 to $2.5 \%$, others suggest that chlorhexidine is the ideal irrigant; ${ }^{8,19}$ additional studies are still needed to elucidate this controversy. Taking into account the need for root canal disinfection and the lack of consensus on the best irrigant solution, concentration, and application protocol, PDT has been considered a viable alternative for endodontic cleaning. ${ }^{20,21}$ The PDT can be used as an adjunct to conventional endodontic treatment without damaging the cells of the periapical region. ${ }^{22}$ Furthermore, compared with conventional antimicrobial therapy, it has the advantage of not triggering any mechanisms of microbial resistance, and can be used numerous times, as it shows no cumulative effect. ${ }^{21,22}$ All macromolecules of microbial cells are potential targets for highly reactive oxygen species. ${ }^{23}$ Thus, the antimicrobial effect of PDT has been the subject of several studies. $8,15,24,25$

The antimicrobial effects of different disinfection protocols with or without the use of PDT have been evaluated. Even in protocols that employed PDT alone, reductions in microbial burden were verified. ${ }^{26-28}$ Other studies compared PDT with different irrigant solutions used during endodontic treatment, and found better results for microbial reduction. ${ }^{15}$ Soukos et a ${ }^{26}$ investigated the effect of PDT with a diode laser at a wavelength of $665 \mathrm{~nm}$ in the root canals of extracted and infected teeth. The results showed the inoculation of microorganisms, with the exception of E. faecalis, for which only a reduction was achieved. The difference is likely to be associated with the organization of E. faecalis in the form of a biofilm, as reported elsewhere. ${ }^{10}$ Pinheiro et $\mathrm{al}^{29}$ studied the antimicrobial action of diode-laser PDT in primary teeth with pulp necrosis after conventional endodontic treatment. Conventional endodontic treatment reduced the microbial burden by $82.59 \%$; after PDT, a $98.37 \%$ reduction was achieved. Garcez et $\mathrm{al}^{30}$ evaluated the effect of PDT in endodontic retreatment, and concluded that the combination of PDT with conventional endodontic treatment reduces microorganism counts. Queiroga et $\mathrm{al}^{31}$ evaluated the effectiveness of different laser dosages $(60,120$, and $180 \mathrm{~J} / \mathrm{cm}^{2}$ ) on Candida spp., and concluded that the higher doses were most effective, achieving $78 \%$ reductions in microbial burden. Vaziri et $\mathrm{al}^{32}$ analyzed the combined use of PDT and $2.5 \% \mathrm{NaOCl}$ irrigation and found complete elimination of E. faecalis in the canal systems of singlerooted teeth. Filipov et $\mathrm{l}^{33}$ investigated the antimicrobial effect of PDT on 5-day-old E. faecalis biofilm and Candida 
albicans, by scanning electron microscopy, and concluded that it has potential to be a good alternative or adjunct to conventional root canal disinfection methods.

The PDT can be used as an adjunct to endodontic treatment, ${ }^{1}$ but for maximum effectiveness to be achieved with this therapy, additional studies should be conducted to determine the optimal settings for parameters, such as dose, power, photosensitizer molecule and concentration, pre-irradiation time, and exposure.

\section{CONCLUSION}

The PDT with a diode laser at the $660 \mathrm{~nm}$ wavelength effectively reduced E. faecalis burden. However, root canals treated solely with laser irradiation at $18 \mathrm{~J}$ for 180 seconds, without irrigation, had higher bacterial contamination than groups in which $\mathrm{NaOCl}$ irrigation was employed, with or without laser irradiation.

\section{REFERENCES}

1. Oliveira JC, Alves FR, Uzeda M, Rôças IN, Siqueira JF Jr. Influence of serum and necrotic soft tissue on the antimicrobial effects of intracanal medicaments. Braz Dent J 2010; 21(4):295-300.

2. Siqueira JF Jr, Rôças IN. Polymerase chain reaction-based analysis of microorganisms associated with failed endodontic treatment. Oral Surg Oral Med Oral Pathol Oral Radiol Endod 2004 Jan;97(1):85-94.

3. Estrela C, Sousa-Neto MD, Alves DR, Alencar AH, Santos TO, Pécora JD. A preliminary study of the antibacterial potential of cetylpyridinium chloride in root canals infected by E. faecalis. Braz Dent J 2012;23(6):645-653.

4. Estrela C Gonçalves AH, Decurcio DA, Borges AH, Estrela CR. Influence of strategies for sanitization on success of apical periodontitis therapy. Rev Odontol Bras Central 2012;21(56): 367-375.

5. Pécora JD. Estrela C Bueno MR, Porto OC, Alencar AH, Sousa-Neto MD, Estrela CR. Detection of root canal isthmus in molars by map-reading dynamic using CBCT images. Braz Dent J 2013 Nov-Dec;24(6):569-574.

6. Estrela C, Sydney GB, Figueiredo JA, Estrela CR. A model system to study antimicrobial strategies in endodontic biofilms. J Appl Oral Sci 2009 Apr;17(2):87-91.

7. Hülsmann M. Effects of mechanical instrumentation and chemical irrigation on the root canal dentin and surrounding tissues. Endod Topics 2013 Sep;29(1):55-86.

8. Haapasalo M, Shen Y, Qian W, Gao Y. Irrigation in endodontics. Dent Clin North Am 2010 Apr;54(2):291-312.

9. Trindade AC, De Figueiredo JA, Steier L, Weber JB. Photodynamic therapy in endodontics: a literature review retrieved no results. Photomed Laser Surg 2015 Mar;33(3): 175-182.

10. Konopka K, Goslinski T. Photodynamic therapy in dentistry. J Dent Res 2007 Aug;86(8):694-707.

11. Portenier I, Waltimo TM, Haapasalo M. Enterococcus faecalisthe root canal survivor and "star" in post-treatment disease. Endod Topics 2003 Nov;6(1):135-159.

12. Estrela C, Silva JA, de Alencar AH, Leles CR, Decurcio DA. Efficacy of sodium hypochlorite and chlorhexidine against
Enterococcus faecalis—a systematic review. J Appl Oral Sci 2008 Nov-Dec;16(6):364-368.

13. AL-Ahmad A, Müller N, Wiedmann-AL-Ahmad M, Sava I, Hübner J, Follo M, Schirrmeister J, Hellwig E. Endodontic and salivary isolates of Enterococcus faecalis integrate into biofilm from human salivary bacteria cultivated in vitro. J Endod 2009 Jul;35(7):986-991.

14. Arias-Moliz MT, Ferrer-Luque CM, Espigares-García M, Baca P. Enterococcus faecalis biofilms eradication by root canal irrigants. J Endod 2009 May;35(5):711-714.

15. Rios A, He J, Glickman GN, Spears R, Schneiderman ED, Honeyman AL. Evaluation of photodynamic therapy using a light-emitting diode lamp against Enterococcus faecalis in extracted human teeth. J Endod 2011 Jun;37(6):856-859.

16. Stojicic S, Amorim H, Shen Y, Haapasalo M. Ex vivo killing of Enterococcus faecalis and mixed plaque bacteria in planktonic and biofilm culture by modified photoactivated disinfection. Int Endod J 2013 Jul;46(7):649-659.

17. Usha HL, Kaiwar A, Mehta D. Biofilm in endodontics: new understanding to an old problem. Int J Contemp Dent 2010 Dec;1(3):44-51.

18. Bago Juric I, Plecko V, Anic I, Plesko S, Jakovljevic S, Rocca JP, Medioni E. Antimicrobial efficacy of photodynamic therapy, Nd:YAG laser and QMiX solution against Enterococcus faecalis biofilm. Photodiagnosis Photodyn Ther 2016 Mar;13: 238-243.

19. de Gregorio C, Estevez R, Cisneros R, Paranjpe A, Cohenca N. Efficacy of different irrigation and activation systems on the penetration of sodium hypochlorite into simulated lateral canals and up to working length: an in vitro study. J Endod 2010 Jul;36(7):1216-1221.

20. Silva LA, Novaes AB Jr, de Oliveira RR, Nelson-Filho P, Santamaria M Jr, Silva RA. Antimicrobial photodynamic therapy for the treatment of teeth with apical periodontitis: a histopathological evaluation. J Endod 2012 Mar;38(3): 360-366.

21. Ok E, Ertas H, Saygili G, Gok T. Effect of photo-activated disinfection on bond strength of three different root canal sealers. Eur J Dent 2014 Jan;8(1):85-89.

22. Xu Y, Young MJ, Battaglino RA, Morse LR, Fontana CR, Pagonis TC, Kent R, Soukos NS. Endodontic antimicrobial photodynamic therapy: safety assessment in mammalian cell cultures. J Endod 2009 Nov;35(11):1567-1572.

23. Soukos NS, Goodson JM. Photodynamic therapy in the control of oral biofilms. Periodontol 20002011 Feb;55(1):143-166.

24. Bago I, Plečko V, Gabrić Pandurić D, Schauperl Z, Baraba A, Anić I. Antimicrobial efficacy of a high-power diode laser, photo-activated disinfection, conventional and sonic activated irrigation during root canal treatment. Int Endod J 2013 Apr;46(4):339-347.

25. Eldeniz AU, Guneser MB, Akbulut MB. Comparative antifungal efficacy of light-activated disinfection and octenidine hydrochloride with contemporary endodontic irrigants. Lasers Med Sci 2015 Feb;30(2):669-675.

26. Soukos NS, Chen PS, Morris JT, Ruggiero K, Abernethy AD, Som S, Foschi F, Doucette S, Bammann LL, Fontana CR, et al. Photodynamic therapy for endodontic disinfection. J Endod 2006 Oct;32(10):979-984.

27. Schlafer S, Vaeth M, Horsted-BIndslev P, Frandsen EV. Endodontic photoactivated disinfection using a conventional light source: an in vitro and ex vivo study. Oral Surg Oral Med Oral Pathol Oral Radiol Endod 2010 Apr;109(4):634-641. 
28. Fonseca MB, Júnior PO, Pallota RC, Filho HF, Denardin OV, Rapoport A, Dedivitis RA, Veronezi JF, Genovese WJ, Ricardo AL. Photodynamic therapy for root canals infected with Enterococcus faecalis. Photomed Laser Surg 2008 Jun;26(3):209-213.

29. PinheiroSL,SchenkaAA, NetoAA, deSouza CP, RodriguezHM, Ribeiro MC. Photodynamic therapy in endodontic treatment of deciduous teeth. Lasers Med Sci 2009 Jul;24(4):521-526.

30. Garcez AS, Fregnani ER, Rodriguez HM, Nunez SC, Sabino CP, Suzuki H, Ribeiro MS. The use of optical fiber in endodontic photodynamic therapy. Is it really relevant? Lasers Med Sci 2013 Jan;28(1):79-85.
31. Queiroga AS, Trajano VN, Lima EO, Ferreira AF, Queiroga AS, Limeira Fa Jr. In vitro photodynamic inactivation of Candida spp by different doses of low power laser light. Photodiagnosis Photodyn Ther 2011 Dec;8(4):332-336.

32. Vaziri S, Kangarlou A, Shahbazi R, Nazari Nasab A, Naseri M. Comparison of the bactericidal efficacy of photodynamic therapy, $2.5 \%$ sodium hypochlorite, and $2 \%$ chlorhexidine against Enterococcous faecalis in root canals; an in vitro study. Dent Res J (Isfahan) 2012 Sep;9(5):613-618.

33. Filipov I, Markova K, Boyadzhieva E. Efficiency of photoactivate disinfection on experimental biofilm—scanning electron microscopy results. J IMAB 2013 Oct;19(4):383-387. 